\title{
Production of interferon in respiratory syncytial virus bronchiolitis
}

\author{
D ISAACS \\ Infectious Disease Unit, Department of Paediatrics, John Radcliffe Hospital, Oxford
}

SUMMARY Production of interferon alfa in vitro was significantly reduced during acute respiratory syncytial virus bronchiolitis but subsequently returned to normal. Nasopharyngeal and endotracheal interferon alfa were detected intermittently and in low concentrations. The degree of impairment of in vitro production and poor in vivo production of interferon alfa suggest the need for a therapeutic trial of nebulised or systemic interferon in acute bronchiolitis.

Infection by respiratory syncytial virus is one of the main causes of infant morbidity and mortality throughout the world causing annual winter epidemics of bronchiolitis with or without pneumonia, yet comparatively little is known about the mechanisms of resistance to-and recovery frominfection. ${ }^{1}$ Maternal antibody does not completely protect against infection and some of the most severe infections occur in infants with the highest titres of passive antibody. Pre-existing secretory antibody in adults correlates with protection ${ }^{2}$ but there is no good evidence of similar protection in infants, ${ }^{3}$ although the appearance of secretory IgA correlates with falling titres of virus in infected infants. ${ }^{4}$

Local production of interferon is an important defence mechanism in many respiratory virus infections, and may limit viral replication until other host defence mechanisms (such as local and systemic antibody production) are activated. Little or no nasal interferon is produced in respiratory syncytial virus infection compared with other respiratory virus infections. ${ }^{56}$ Nevertheless, respiratory syncytial virus is acutely sensitive to interferon in vitro ${ }^{7}$ and evidence of poor interferon production suggests a disease in which the therapeutic use of interferon could be envisaged. The aim of the present study was to examine further the production of interferon in vitro and in vivo in infants with respiratory syncytial virus bronchiolitis.

\section{Patients and methods}

The index group comprised 64 infants aged 2 weeks to 12 months with a clinical diagnosis of bronchiolitis according to the criteria of Court ${ }^{8}$ with or without radiological evidence of pneumonia. All were confirmed as positive for respiratory syncytial virus by indirect immunofluorescence on nasopharyngeal secretions using a bovine antiserum against respiratory syncytial virus (Central Public Health Laboratory) and a fluorescein conjugated antibovine antiserum (Wellcome). Patients were classified by severity of disease into the following groups according to the amount of treatment they needed while in hospital: group I-oral feeds; group II-nasogastric feeds; group III-nasogastric feeds and supplemental oxygen; group IV-intravenous fluids and supplemental oxygen; and group $\mathrm{V}$-artificial ventilation.

The index group were studied as soon as possible after admission to hospital (acute) and at least two weeks after clinical recovery (convalescent). The control group comprised age matched infants in hospital for non-infectious conditions, mainly cardiac or surgical patients.

Venous blood was obtained from the index group during the acute phase and during convalescence, and from the healthy controls, and heparinised. Peripheral blood mononuclear cells were obtained by separation on 'Ficoll-Paque' (Sigma), washed and resuspended at $1 \times 10 \% \mathrm{ml}$ in RPMI and $10 \%$ fetal calf serum, $60 \mu \mathrm{g} / \mathrm{ml}$ penicillin, $100 \mu \mathrm{g} / \mathrm{ml}$ streptomycin, and $300 \mu \mathrm{g} / \mathrm{ml}$ glutamine. Then $2 \times 10^{6}$ cells were incubated in $5 \%$ carbon dioxide with 50 haemagglutinating units of Newcastle disease virus (a potent in vitro stimulator of interferon alfa production) for 24 hours. A further $2 \times 10^{6}$ cells were incubated in 5\% carbon dioxide for seven days in the presence of $50 \mu \mathrm{l}$ phytohaemagglutinin (Wellcome) to stimulate production of interferon gamma. Supernatants were frozen at $-70^{\circ} \mathrm{C}$ until assayed. 
Nasopharyngeal secretions were obtained from index patients (serially when possible) during the acute phase of the infection by suction using a mucus aspirator and trap (Vygon) at the same time as routine nasal suction was being carried out. Endotracheal secretions were obtained from infants requiring artificial ventilation using the same mucus aspirator and a thin catheter.

Whenever possible serial tenfold dilutions of the nasopharyngeal or endotracheal secretions were made in phosphate buffered saline and $0.2 \mathrm{ml}$ duplicate dilutions inoculated on to monolayers of HEp2 cells. These were grown in roller drums at $33^{\circ} \mathrm{C}$ for two weeks or until the typical cytopathic effect developed. The titre of respiratory syncytial virus in a specimen was taken as the reciprocal of the highest dilution in which the cytopathic effect was seen. Supernatants from the original secretions, diluted 5-10 times in phosphate buffered saline A, were frozen at $-70^{\circ} \mathrm{C}$ until assayed for interferon.

In vitro mononuclear cell culture supernatants, and supernatants from nasopharyngeal and endotracheal secretions, were assayed for interferon alfa and interferon gamma with separate highly sensitive and specific immunoradiometric assays (Boots Celltech).

Statistical analysis was by Student's $t$ test and $\chi^{2}$ testing. Informed parental consent was obtained and the study was approved by the central Oxford research ethics committee.

\section{Results}

Peripheral blood mononuclear cell interferon alfa production in vitro was significantly lower in the 64 patients with acute respiratory syncytial virus infections than in the 21 control subjects (geometric mean (1 SD) 26.8 (6.5-109.6) compared with 138.9 (23.6-818.5) IU/ml, p<0.001) (fig 1). This was not caused by a primary defect in in vitro production of interferon alfa, because production of interferon alfa was normal in 22 of the patients with respiratory syncytial virus when they were convalescent (geometric mean (1 SD) $166.6(55 \cdot 6-500) \mathrm{IU} / \mathrm{ml}$, $\mathrm{p}<0.001$ compared with the patients with acute infections but not significantly different from the control subjects). There was no correlation between severity of disease and in vitro production of interferon alfa (fig 2).

There was no difference between in vitro production of interferon gamma by 41 patients during acute respiratory syncytial virus infection (geometric mean (1 SD) $39 \cdot 3(8 \cdot 0-193 \cdot 1) \mathrm{IU} / \mathrm{ml}), 14$ convalescent patients $(38.5(8 \cdot 3-179) \mathrm{IU} / \mathrm{ml})$, and 20 control subjects $(39 \cdot 7(5 \cdot 7-277 \cdot 3) \mathrm{IU} / \mathrm{ml})$.

Interferon alfa was detected in $52(45 \%)$ of 115 nasopharyngeal samples tested. It was generally present in small amounts (geometric mean titre (1 SD) $3.6(1 \cdot 1-11 \cdot 3) \mathrm{IU} / \mathrm{ml})$, although occasional high titres (one of 80 and one of $85 \mathrm{IU} / \mathrm{ml}$ ) were recorded. Only single samples were available from 50 patients: $21(42 \%)$ were positive with a geometric mean titre of $2.9 \mathrm{IU} / \mathrm{ml}$. Multiple samples were available from 21 (more severely ill) patients, and of the 65 samples tested $31(47 \cdot 8 \%)$ contained interferon alfa at a geometric mean titre (1 SD) of $4 \cdot 1(1 \cdot 4-11 \cdot 8) \mathrm{IU} / \mathrm{ml}$ with a range of $1-20 \mathrm{IU} / \mathrm{ml}$. Interferon alfa was intermittently detected in serial samples from a number of infants with severe bronchiolitis, and its presence or absence correlated poorly with the detection of the virus. Overall there

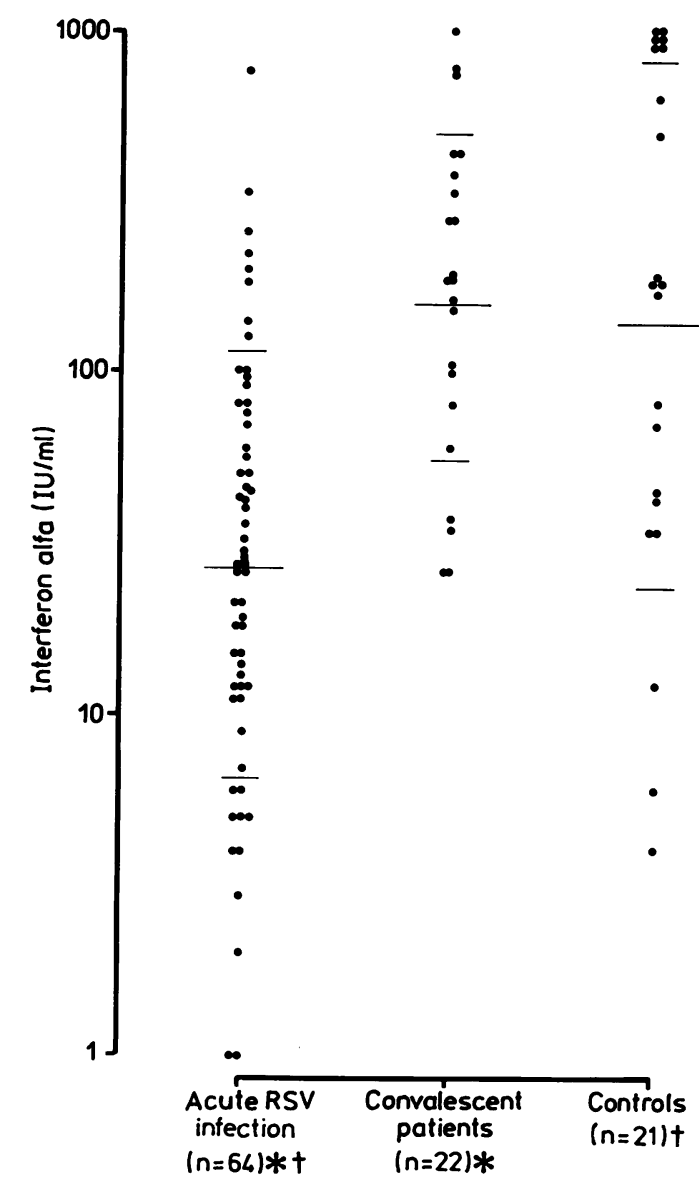

Fig 1 In vitro interferon alfa production by peripheral blood mononuclear cells from 64 infants with acute respiratory syncytial virus (RSV) infection, 22 convalescent patients, and 21 control subjects. Wide bars $=$ geometric mean, narrow bars $=1 S D ;{ }^{*}+p<0.001$. 


\section{Isaacs}

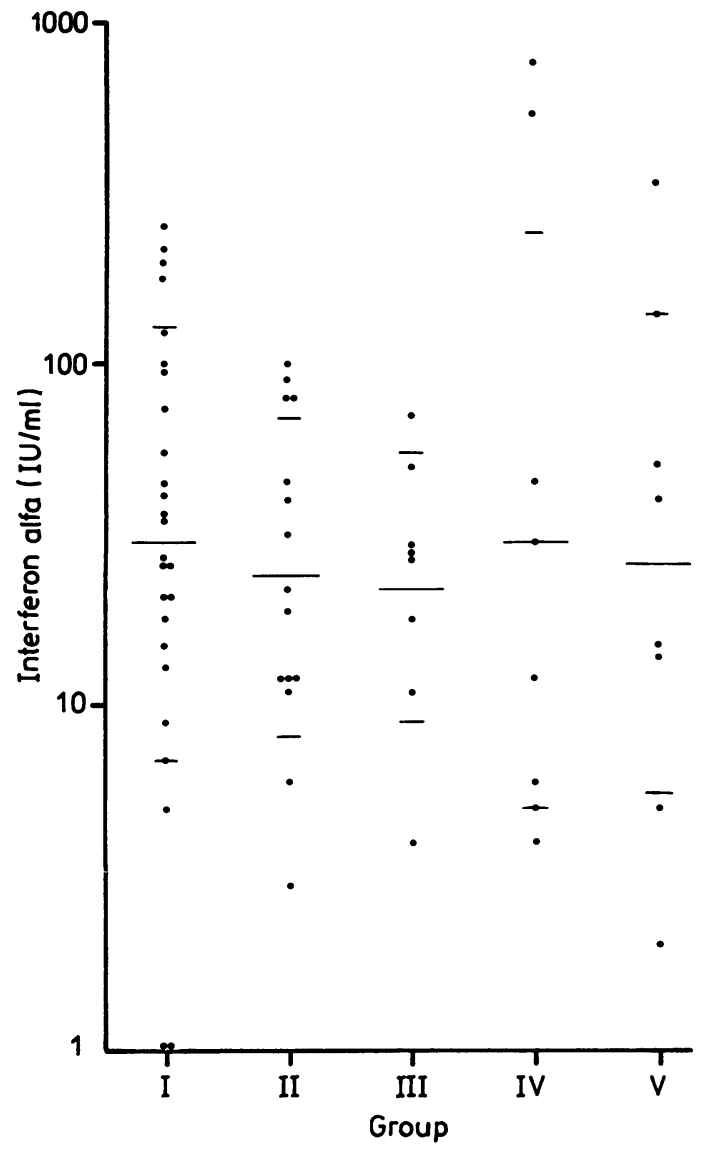

Fig 2 In vitro interferon alfa production by peripheral blood mononuclear cells from infants with acute respiratory syncytial virus infection according to disease severity. Wide bars = geometric mean, narrow bars $=1 S D$. There was no significant differences among the groups.

was no significant correlation between interferon alfa titres and titres of respiratory syncytial virus in nasopharyngeal secretions in which either interferon alfa or virus were detected (fig 3 ). In only one of the seven endotracheal aspirates tested was interferon alfa detected (titre $5 \mathrm{IU} / \mathrm{ml}$ ). Interferon gamma was not detected in any of 16 nasopharyngeal and seven endotracheal samples tested.

\section{Discussion}

A number of features of respiratory syncytial virus infection are poorly understood. Mechanisms of resistance to and recovery from infection in infants are not clear, but neither serum antibody nor

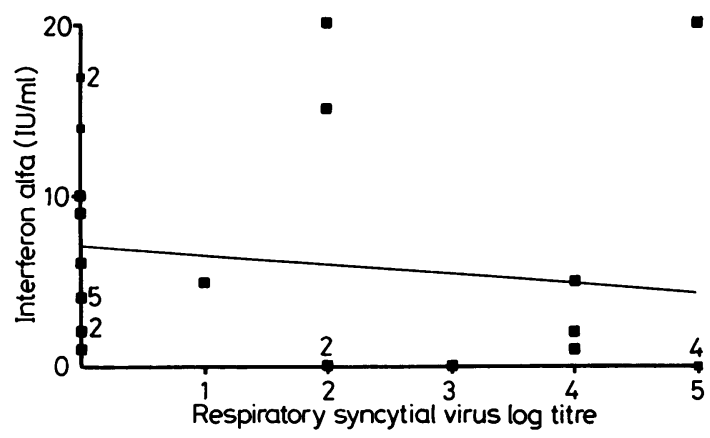

Fig 3 In vitro interferon alfa titres and log respiratory syncytial virus titres on nasopharyngeal secretions from infants with acute respiratory syncytial virus bronchiolitis. Respiratory syncytial virus log titre is the reciprocal of greatest dilution that caused a cytopathic effect on HEp2 cells. Small numbers represent multiple superimposed values. $y=7 \cdot 0349-0 \cdot 5507 x, N S$.

secretory antibody titres correlate well with protection or recovery. Cell mediated immunity (in the form of respiratory syncytial virus specific cytotoxic $T$ cells) may be important in recovery and can sometimes be detected in the peripheral blood of even young infants. ${ }^{9}$ There is a honeymoon period of six weeks after birth when infection and severe disease are unusual, but after this period almost all exposed infants become infected and about $40 \%$ develop lower respiratory tract infections. ${ }^{10}$ Reinfections in childhood and into adult life, although successively milder, are common. ${ }^{11} \mathrm{Up}$ to $30 \%$ of infants with respiratory syncytial virus bronchiolitis later develop asthma, and the mechanism may be altered antigen presentation to the lungs after structural damage by respiratory syncytial virus. The new antiviral agent, ribavirin, has promising activity against respiratory syncytial virus but morbidity and mortality of severe respiratory syncytial virus infection remain high and it has not yet been shown whether ribavirin can reduce these. ${ }^{12}$

The results of this study, and those of Hall et al and McIntosh, ${ }^{6}$ suggest that it is unlikely that production of interferon alfa is an important in vivo mechanism for preventing or ameliorating respiratory syncytial virus infection. It is not understood why respiratory syncytial virus is such a poor inducer of interferon alfa, but this has now been shown both in vivo and in vitro. ${ }^{13}$ We have also shown that there is significant but reversible impairment of the ability of mononuclear cells from infected infants to produce interferon alfa in vitro in response to a standard viral stimulus. Newcastle disease virus, a paramyxovirus, was deliberately chosen because it is similar to respiratory syncytial virus. Although the 
degree of impairment of production of interferon alfa could not be associated with the severity of the disease, it may well be an important sign of the transient suppressive effect of respiratory syncytial virus infection on interferon production.

Natural or recombinant interferon alfa has little or no therapeutic effect on respiratory virus infections when given intranasally or systemically after infection is established. ${ }^{14}$ This is probably because respiratory viruses are generally potent stimulators of local, nasal, and sometimes serum production of interferon, ${ }^{5}$ which may already be maximal by the time treatment with interferon can be started.

On the other hand, interferon alfa can be given prophylactically to prevent respiratory infections. Two recent studies have shown that an intranasal spray of interferon taken prophylactically by the family contacts of an index case with a cold, protected the contacts against developing colds caused by rhinoviruses, though not against infections due to parainfluenza, influenza, coronaviruses, or Mycoplasma pneumoniae. ${ }^{15} 16$

If the possible use of interferon against respiratory syncytial virus infection is to be considered there are two likely approaches: to use a nasal spray prophylactically in infants in contact with a cold (contact prophylaxis) or to use interferon to treat infants with established bronchiolitis (therapeutic use). Respiratory syncytial virus infections are generally introduced into the family by a schoolchild ${ }^{11}$ so that it is theoretically possible to give an intranasal spray to parents to be given to a baby (perhaps any infants less than 6 months old or those at high risk of severe respiratory syncytial virus infection) when another family member develops a winter respiratory infection (contact prophylaxis). Current intranasal preparations have, however, caused considerable local toxicity in adults leading to nasal irritation, hyperaemia, bleeding, and ulceration ${ }^{15} 16$ and it is likely that drops or sprays would be poorly tolerated by babies.

There is good reason to suspect that interferon might be successful in treating respiratory syncytial virus infection, even when infection is established. Local nasal production of interferon alfa is high during most respiratory virus infections but low during respiratory syncytial virus infection. ${ }^{56} \mathrm{We}$ have now shown that mononuclear cells from infants with respiratory syncytial virus bronchiolitis produce significantly less interferon alfa than cells from control subjects or cells from infants recovered from respiratory syncytial virus, suggesting a suppressive effect on production of interferon alfa by respiratory syncytial virus. On the other hand, respiratory syncytial virus is extremely sensitive to the action of interferon in vitro. ${ }^{7}$ The combination of a virus that does not induce production of interferon but which is highly sensitive to its action-as in respiratory syncytial virus bronchiolitis-would seem ideal for a therapeutic trial of interferon. Because the main damage is occurring in the bronchioles nebulised interferon is likely to be the most effective form, and there is already evidence that nebulised interferon is well tolerated by adults. ${ }^{17}$

David Isaacs is funded by the Wellcome Trust and this work was also supported by a grant from the district research committee. I thank Trevor Berbick, Karen Sayer, and Elizabeth Vidale for technical help; Erica Woodward, her colleagues, and the nursing staff for help in collecting specimens; and Maggie Ellis for typing the manuscript.

\section{References}

${ }^{1}$ McIntosh K, Fishaut MJ. Immunopathologic mechanisms in lower respiratory tract disease of infants due to respiratory syncytial virus. Prog Med Virol 1980;26:94-118.

2 Mills J, Van Kirk JE, Wright PF, et al. Experimental respiratory syncytial virus infection of adults. Possible mechanisms of resistance to infection and illness. J Immunol 1971;107:123-30.

${ }^{3}$ Nandapalan N, Taylor C. Scott R, Toms GL. Mammary immunity in mothers of infants with respiratory syncytial virus infection. J Med Virol 1987;22:277-87.

${ }^{4}$ McIntosh K, McQuillin J, Gardner PS. Cell-free and cell-bound antibody in nasal secretions from infants with respiratory syncytial virus infection. Infect Immun 1979;23:276-81.

5 Hall CB, Douglas RG Jr, Simons RL, Geiman JM. Interferon production in infants with respiratory syncytial, influenza and parainfluenza virus infections. J Pediatr 1978;93:28-32.

6 McIntosh K. Interferon in nasal secretions from infants with viral respiratory tract infections. $J$ Pediatr 1978;93:33-6.

${ }^{7}$ Moehring JM, Forsyth BR. The role of the interferon system in respiratory syncytial virus infections. Proc Soc Exp Biol Med 1971;138:1009-14.

8 Court SDM. The definition of acute respiratory diseases in children. Postgrad Med J 1973;49:771-6.

9 Isaacs D, Bangham CRM, McMichael AJ. Cell-mediated cytotoxic response to respiratory syncytial virus in infants with bronchiolitis. Lancet 1987;ii:769-71.

${ }^{10}$ Hall CB. Respiratory syncytial virus. In: Feigin RD, Cherry JD, eds. Textbook of pediatric infectious diseases. 2nd ed. Philadelphia: Saunders, 1987:1653-76.

${ }^{11}$ Hall CB, Geiman JM, Biggar R, et al. Respiratory syncytial virus infections within families. $N$ Engl J Med 1976;294:414-9.

12 Isaacs D. Ribavirin. Pediatrics 1987;79:289-91.

13 Chonmaitree T, Roberts NJ, Douglas RG, Hall CB, Simons RL. Interferon production by human mononuclear leukocytes: differences between respiratory syncytial virus and influenza viruses. Infect Immun 1981;32:300-3.

14 Scott GM, Tyrrell DAJ. Interferon: therapeutic fact or fiction for the '80s? $\mathrm{Br}$ Med $J$ 1980;280:1558-62.

15 Douglas RM, Moore BW, Miles HB, et al. Prophylactic efficacy of intranasal alpha $a_{2}$-interferon against rhinovirus infections in the family setting. $N$ Engl $J$ Med 1986;314:65-70.

16 Hayden FG, Albrecht JK, Kaiser DL, Gwaltney JM. Prevention of natural colds by contact prophylaxis with intranasal alpha $a_{2}$ interferon. $N$ Engl $J$ Med 1986;314:71-5.

17 Greenberg SB, Harmon MW, Cough RB, et al. Prophylactic effect of low doses of leukocyte interferon against infection with rhinovirus. $J$ Infect Dis 1982;145:542-6.

Correspondence to Dr D Isaacs, Infectious Disease Unit, Department of Paediatrics, John Radcliffe Hospital, Oxford OX3 9DU.

Accepted 8 August 1988 